\title{
Isotope Dating of the Potash and Rock Salt Deposit at Bamnet Narong, NE-Thailand
}

\author{
Bent T. Hansen ${ }^{*}$, Klaus Wemmer ${ }^{1}$, Monique Eckhardt ${ }^{1}$, Prinya Putthapiban², \\ San Assavapatchara ${ }^{3}$ \\ ${ }^{1}$ Geoscience Center Göttingen, University of Göttingen, Göttingen, Germany \\ ${ }^{2}$ Geoscience Programme, Kanchanaburi Campus, Mahidol University, Kanchanaburi, Thailand \\ ${ }^{3}$ Department of Mineral Resources, Bureau of Geological Survey, Bangkok, Thailand \\ Email: "bhansen@gwdg.de
}

Received 27 June 2016; accepted 19 August 2016; published 22 August 2016

Copyright (C) 2016 by authors and Scientific Research Publishing Inc.

This work is licensed under the Creative Commons Attribution International License (CC BY). http://creativecommons.org/licenses/by/4.0/

(c) (i) Open Access

\section{Abstract}

Bamnet Narong is located in northeastern Thailand (Chaiyaphum Province). It is the largest salt mine in the country and has been mined for decades. The landscape in this part of Thailand is characterised by a low plateau, which is called the Khorat Plateau. The plateau is divided into two basins by the Phu Phan Range, the Sakhon Nakhon Basin in the north and the Khorat Basin in the south. The analysed potashes and rock salts are deposited in the Maha Sarakham Formation, which represents the salt-bearing strata of the Khorat Basin. The stratigraphic age of this deposit has been debated since the late 1960's. The assigned ages range from Mid-Cretaceous to Late Cretaceous and up to the Eocene. In this study different isotopic dating systems ( $\mathrm{Rb}-\mathrm{Sr}, \mathrm{Sr}-\mathrm{Sr}, \mathrm{K}-\mathrm{Ar}$ and $\mathrm{K}$-Ca) were applied. The stratigraphic age for the time of deposition was confirmed to be Mid Cretaceous (Cenomanian). Furthermore, the homogeneity of the carnallites was investigated in order to trace a possible redistribution of rubidium.

\section{Keywords}

Isotope Dating, Salt Deposits, Mid-Cretaceous, Asian Potash Mine, Thailand

\section{Introduction}

Bamnet Narong is located in northeastern Thailand (Chaiyaphum Province) and hosts the largest salt mine

${ }^{*}$ Corresponding author.

How to cite this paper: Hansen, B.T., Wemmer, K., Eckhardt, M., Putthapiban, P. and Assavapatchara, S. (2016) Isotope Dating of the Potash and Rock Salt Deposit at Bamnet Narong, NE-Thailand. Open Journal of Geology, 6, 875-894.

http://dx.doi.org/10.4236/ojg.2016.68067 
(Asian Potash Mine) in Thailand that was mined for decades. Geographically, it is considered part of the western edge of the Khorat Basin (Figure 1). Stratigraphically this salt deposit is part of the so-called Maha Sarakham Formation and represents one of the world's largest salt deposits. The stratigraphic and palaeontological study of the Maha Sarakham Formation, as well as the whole Khorat Basin began in the early 1960's, whereas the salt resources and related issues were studied during the 1970's. The stratigraphic age of this formation has been highly debated since the late 1970's. The Maha Sarakham Formation was first named by [1] who assigned an age from the Late Cretaceous to the Eocene. Based on palynological evidence [2] a Mid-Cretaceous age was proposed for the deposition. In 1990 doubt was cast by [3] who compared it with the depth of core samples and then specified an age of Mid-Late Albian to Cenomanian. Geochemical studies of [4] on the sulphur and oxygen isotopes of the Maha Sarakham anhydrites yielded an age of Neocomian (lower Cretaceous) to Cenomanian. Multiple isotope analyses on various halite, anhydrite and carnallite samples as well as one clay sample from the shaft at Bamnet Narong pointed to a deposition age of about $95 \mathrm{Ma}$ (Cenomanian) [5]. This agrees with the assumed Aptian-Albian age from [6], which was obtained from vertebrate fossils of the underlying Khok Kruat Formation.

The research objectives of this study are to date the Maha Sarakham Formation by using the K-Ca and Rb-Sr isotope systems in comparison with the existing data. K-Ca decay is used for the carnallite samples, which were collected from a $1200 \mathrm{~m}$ long profile in the shaft of the Bamnet Narong (Asian Potash Mine). Rb-Sr decay is used for the anhydrites which were in parts already analysed [5]. These data were subsequently compared with the seawater evolution curve, LOWESS curve [7]. Anhydrites are used because they are very stable in regards to the redistribution of rubidium, as their content of rubidium is negligible. Another aim of the present study is the geochemical characterisation of the carnallites in terms of the variation of specific elements in a small area concerning their potential heterogeneity.

\section{Geological Setting}

\section{Tectonic and Geologic Evolution of the Khorat Plateau}

The Khorat Plateau is framed by an escarpment of mostly steeply dipping sediments, which form slopes on its western and southern margins rising from $600-1000 \mathrm{~m}$ above sea level. The plateau is situated between $14^{\circ} \mathrm{N}$ and $19^{\circ} \mathrm{N}$ and $101^{\circ} \mathrm{E}$ and $106^{\circ} \mathrm{E}$. It is divided by the Phu Pan Range into two depositional basins, the Khorat Basin in the south and the smaller Sakhon Nakhon Basin in the north [8]. In a broader sense it is part of the Indo-

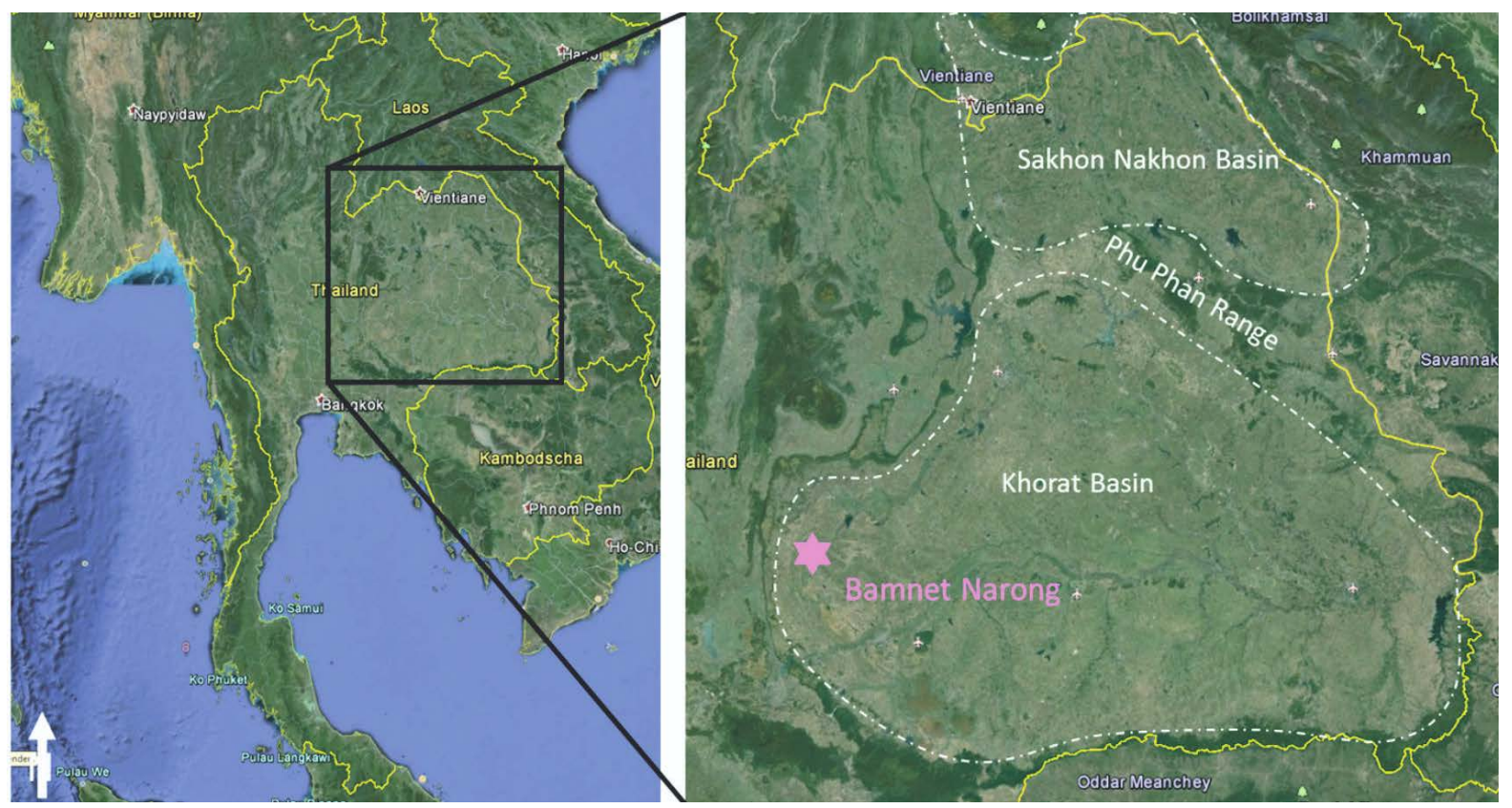

Figure 1. Geographical location of the Khorat Basin, the Phu Phan Range and the northern Sakhon Nakhon Basin. Bamnet Narong is highlighted by a pink star in the western part of the Khorat Basin. Source: Google Maps (query 10.07.2013). 
china Terrane, which originated by rifting of the margin of Gondwana. Furthermore, it represents a broad synclinorium bounded to the west by the Shan Thai Terrane and to the north by the South China Plate [9] [10]. The Khorat Plateau has, in connection with investigations of its hydrocarbon potential, been described as a "saucepan morphology" [11].

The basement of the Khorat Plateau consists of igneous, metamorphic and sedimentary rocks which underlie the Huai Hin Lat Formation. Sedimentation of the Mesozoic rocks began in the Early Triassic, after the Khorat Basin was formed due to extension during the Indosinian Orogeny [13]. The deposition took place in half-graben rift basins, which were developed during this orogeny, and filled with mainly lacustrine and fluviatile clastic sediments. This Triassic sequence is called the Huai Hin Lat Formation. The depositional period of this formation ended in the late Upper Triassic (Norian-Rhaetian) during the first episodes of the Indosinian Orogeny [14]. The following fluvial red-beds sequence was mapped as the Nam Phuong Formation, which represents the beginning of the Khorat Group. Afterwards uplift and erosion events as well as subsidence took place. The following red-bed formations of Cretaceous age are (from bottom to top): The Phu Kradung, the Phra Wihan, the Sao Khua, the Phu Pan and the Khok Kruat Formation. This Cretaceous succession is unconformably overlain by the continental evaporitic Maha Sarakham Formation [15], which was deposited during the Mid-Cretaceous (Albian-Cenomanian) regional folding. This process initiated the uplift of a large scale basin, which was later filled with evaporitic deposits, caused by sea water inflow from the west into the western edge of the basin (Figure 2)): the Phu Kradung, the Phra Wihan, the Sao Khua, the The Maha Sarakham Formation is not part of the Khorat Group. Three transgressions and two regressions with evaporation can be reconstructed during the accumulation of this formation. The youngest Mesozoic formation which overlies the Maha Sarakham Formation is the Phu Tok Formation, which was formed when the sea water regressed entirely. Finally, the Khorat deposits were intruded by granites of Campanian and Cenomanian age. During the Early Paleocene, compression from the northeast, due to continental collision of the Indochina Terrane with the Southeast China Plate (Himalayan Orogeny), and also from back arc compression to the west, resulted in uplift and erosion of a part ( 3000 $\mathrm{m})$ of the Khorat sediments as well as the formation of the NW-SE trending Phu Phan Anticline. The Cenozoic sediments consist of alluvial, eolian and fluvial deposits, as described in [15]-[17].

\section{Stratigraphic and Supposed Ages}

The stratigraphy of the entire Mesozoic succession of the plateau is shown in Figure 3. The continental red-beds of the Mesozoic Khorat Group, which built up most of the Khorat Plateau, unconformably overly the Triassic rocks. The definition of the Khorat Group differs from author to author and is commonly considered to comprise the sediments above the basal Nam Phuong Formation unconformity [17]. Also the exact position of the Jurassic-Cretaceous boundary in the Khorat strata has not been pinpointed until now. The base of the Maha Sarakham Formation has been dated by means of palynological analysis as Mid-Albian-Cenomanian in age. Usually the Nam Phuong Formation is considered to be Late Triassic and the Phu Kradung, Phra Wihan and Sao Khua Formations are related to the Jurassic. However, the Phu Phan and Khok Kruat Formations are assigned to the Early Cretaceous, for example by [15] and [18]. All these age determinations are primarily based on plant macrofossils, pollen and vertebrate remains, e.g. in [19] and [15].

As mentioned above the Khorat Plateau almost consists of Cretaceous rocks (Figure 3). These are slightly deformed, fossiliferous and well-exposed. Thus, the Khorat Plateau received more attention than the Cretaceous rocks elsewhere in Thailand [12]. Most authors assume six formations within the Cretaceous deposits, which are named in ascending order according to their age and are as follows: the Phra Wihan, Sao Khua, Phu Phan, Khok Kruat, Maha Sarakham and Phu Thok Formations.

\subsection{Phra Wihan Formation}

The Phra Wihan Formation crops out in the Phu Phan Range and is also widely distributed around the western and especially the southern rims of the Khorat Plateau. At the southern rim it forms the Dongrek Range which marks the border to Cambodia. This formation is named after the temple mountain of Khao Phra Wihan located at the south-eastern border of the Khorat Plateau. The rocks usually consist of light buff to grey, fine- to coarsegrained quartzitic sandstones and to a lesser extent of siltstones and mudstones with occasional occurrences of conglomerates [12]. They were deposited in a fluvial environment dominated by a high-energy, shallow braided river system and associated floodplains [15]. This formation conformably overlies the Phu Kradung as well as 
the underlying Sao Khua Formation and has a gradational contact to both of them. Its thickness varies between 100 and $250 \mathrm{~m}$. In the central and northern parts of the Phu Phan Anticline the formation overlies the Phu Kradung Formation with a sharp contact [12] [15]. The Phra Wihan Formation dates to around Middle Jurassic/Early Cretaceous in age by [20] on the basis of plants and arthropod fossils (crustaceans and insects). A recent study by [15] proposes a Lower Cretaceous age (Berriasian-Barremian), due to the analyses of palynomorphs which were collected near the base of the formation.

\subsection{Sao Khua Formation}

The Sao Khua Formation crops out throughout the whole Phu Phan Range. The rocks usually consist of an alternation of reddish-brown conglomeratic sandstone, siltstone and mudstone together with common calcretes. The thickness of this formation varies between 100 and $600 \mathrm{~m}$. It was deposited in an environment with lowenergy meandering channels and extensive floodplains. The contact of this formation with the underlying Phra

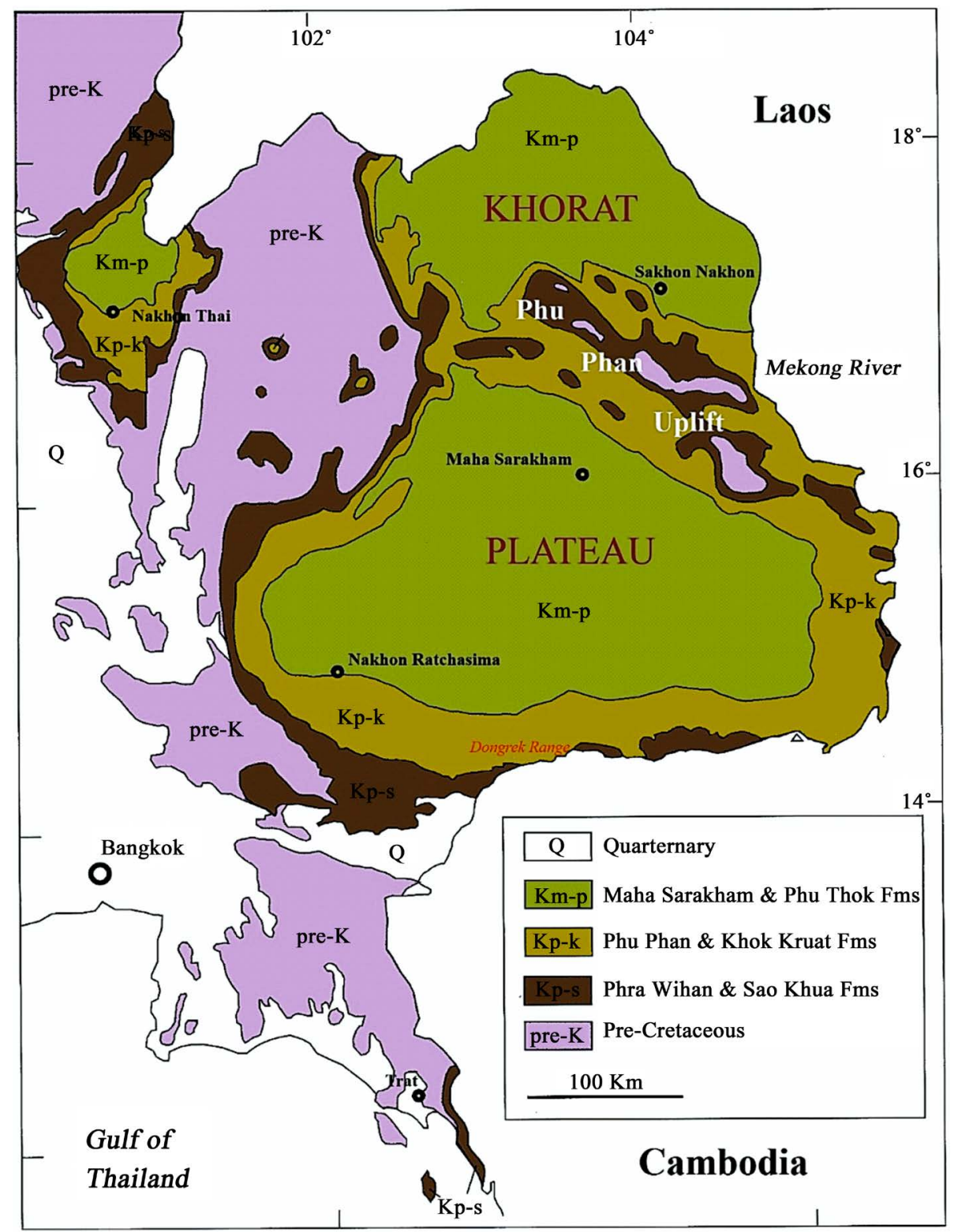

Figure 2. Distribution of Cretaceous strata in NE and SE Thailand. The pre-Cretaceous rocks may be Jurassic or JurassicCretaceous in age [12]. 


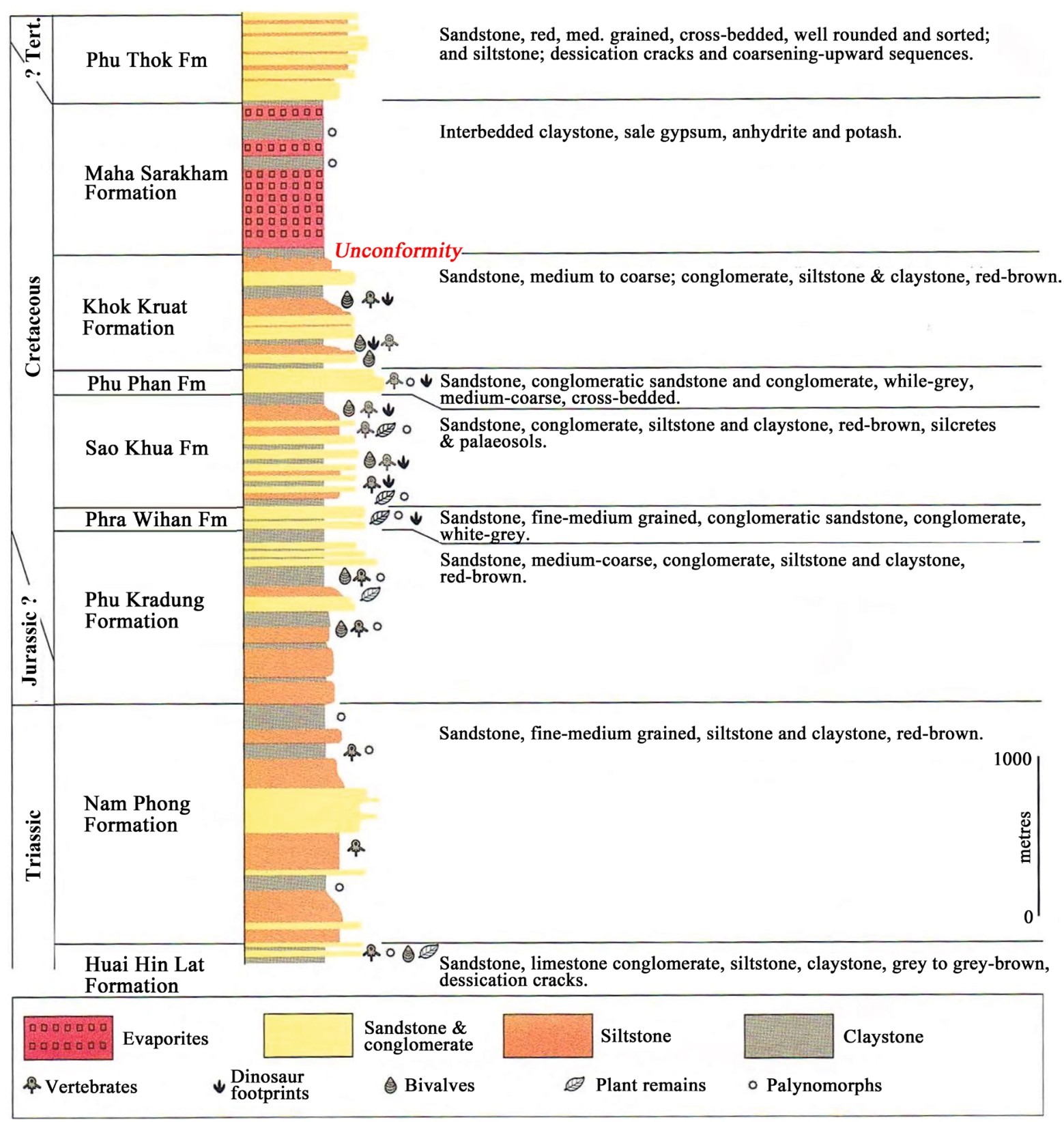

Figure 3. Stratigraphic column of the Mesozoic rocks of the Khorat Plateau, NE Thailand, [12].

Wihan and overlying Phu Phan Formation is gradational and conformable [15]. At the beginning of the Sao Khua Formation it was considered to be Late Jurassic, for example by [21] on the basis of vertebrate remains. This area has the richest and most diverse vertebrate fauna found in Thailand [12]. In contrast, [22] [23] as well as [15]) determined an Early Cretaceous age (Berriasian-Barremian) based on palynological investigations, similar to the Phra Wihan Formation.

\subsection{Phu Phan Formation}

The rocks of the Phu Phan Formation usually consist of greyish-white, medium- to coarse-grained cross-bedded sandstones and lacustrine grey siltstones and mudstones with subordinated conglomerates [12] [15]. Generally, the formation is 75 - 150 m thick and the contact with the underlying Sao Khua Formation is locally erosive or distinctively sharp but mainly conformable and with the overlying Khok Kruat Formation. The supposed depo- 
sitional environment was a high-energy, low-sinuosity braided river system with subordinate floodplains [12] [15]. According to [23] and [15], the age of the formation is Barremian to Aptian, based on the ages of the overand underlying formations and also on palynological studies.

\subsection{Khok Kruat Formation}

The Khok Kruat Formation is widely distributed in the outer parts of the Phu Phan Anticline. It usually comprises reddish-brown, fine- to medium-grained sandstone, siltstone, shale and mudstone with several conglomerate beds [12] [15]. The reddish colour gradually turns into greenish-grey at a few metres below the overlying Basal Anhydrite of the Maha Sarakham Formation. This is a result of subsequent diagenesis, probably from reducing subsurface brines that had percolated through the rocks during the time of burial [24]. The contact with the overlying Maha Sarakham Formation is unconformable [12] [15]. This sharp contact to the Basal Anhydrite has been reported for example by [25] and within seismic profiles by [26]. The depositional environment is expected to have been a meandering river system, less mature than the rivers that deposited the Sao Khua Formation [12]. This assumption of a fluviatile environment with possible marine influence is based on the associated fauna [15]. An age of Late Aptian for the upper parts of the formation was reported by [26] due to palynological evidence. An Aptian to Albian age based on dinosaur findings in the Khok Kruat Formation was also indicated by [27].

\subsection{Maha Sarakham Formation}

The Maha Sarakham Formation comprises four different salt units which principally consist of evaporates separated by red-coloured siliciclastics: Basal Anhydrite, Lower Salt, Potash Zone, Several Colour Bands Salt Unit, Lower Clastic, Middle Salt, Middle Clastic, Upper Salt and Upper Clastic (see Figure 4 for stratigraphy). Its thickness ranges across the basin from 250 to $1100 \mathrm{~m}$ and its appearance varies upon the area controlled by rock salt structures [28]-[30]. The formation overlies the Khok Kruat Formation with a very sharp contact. All three units comprise beds which consist of halite-replaced pseudomorphs of bottom-growth gypsum. The formation was deposited in a hypersaline, landlocked lake within an arid continental desert, hence fossils are rare [15] [30]. In several places of the basin salt domes and salt anticlines are present. Reference [26] reported an Albian to Cenomanian age for them based on palynomorphs. The following is a description of all members including the siliciclastics based on descriptions by [8] [29] and modified after [16]. The rock salt on the Khorat Plateau in both the Khorat and the Sakhon Nakhon Basin has the same characteristics and correlations, which shows that these two basins once formed one large basin during the deposition until the uplift of the Phu Phan Range in the Early Paleocene, (refer to Chapter 2.3 in [29]).

\subsection{Basal Anhydrite Unit}

The Basal Anhydrite Unit represents the base of the Maha Sarakham Formation in both the Khorat and Sakhon Nakhon Basin. This formation overlies the Khok Kruat Formation disconformably and stylolitic surfaces are found [16] [28]. Most of the anhydrite is formed directly or from conversion of gypsum, which existed as beds and clusters with gradational contacts to enveloping sediments [28]. Its thickness varies from 0.7 - $6.2 \mathrm{~m}$ [24].

\subsection{Lower Salt Unit}

The Lower Salt Unit overlies the Basal Anhydrite and the underlying Potash Zone Unit. This rock stratum consists mainly of coarse crystalline, transparent to semitranslucent halite and a minor amount of anhydrite in the form of thin partings [24]. The unit is separated by an anhydrite marker bed into two sequences. [16] named them the Halite L1 and Halite L2 Unit. This marker anhydrite and also the following are a primary one deposited directly from sea water [16]. The contact to the Basal Anhydrite Unit is very sharp and immediate. Reference [24] proposed that this can either be the result from the abrupt change in gypsum solubility as the brine was introduced into the halite saturation field or a result due to pressure solution under burial conditions. The thickness of this unit depends on the position within the basin as well as salt flowage and ranges between 30 - 500 m [29] [31].

\subsection{Potash Zone Unit}

The Potash Zone Unit is located between the Lower Salt and the Several Colour Bands Salt Unit. This unit is 


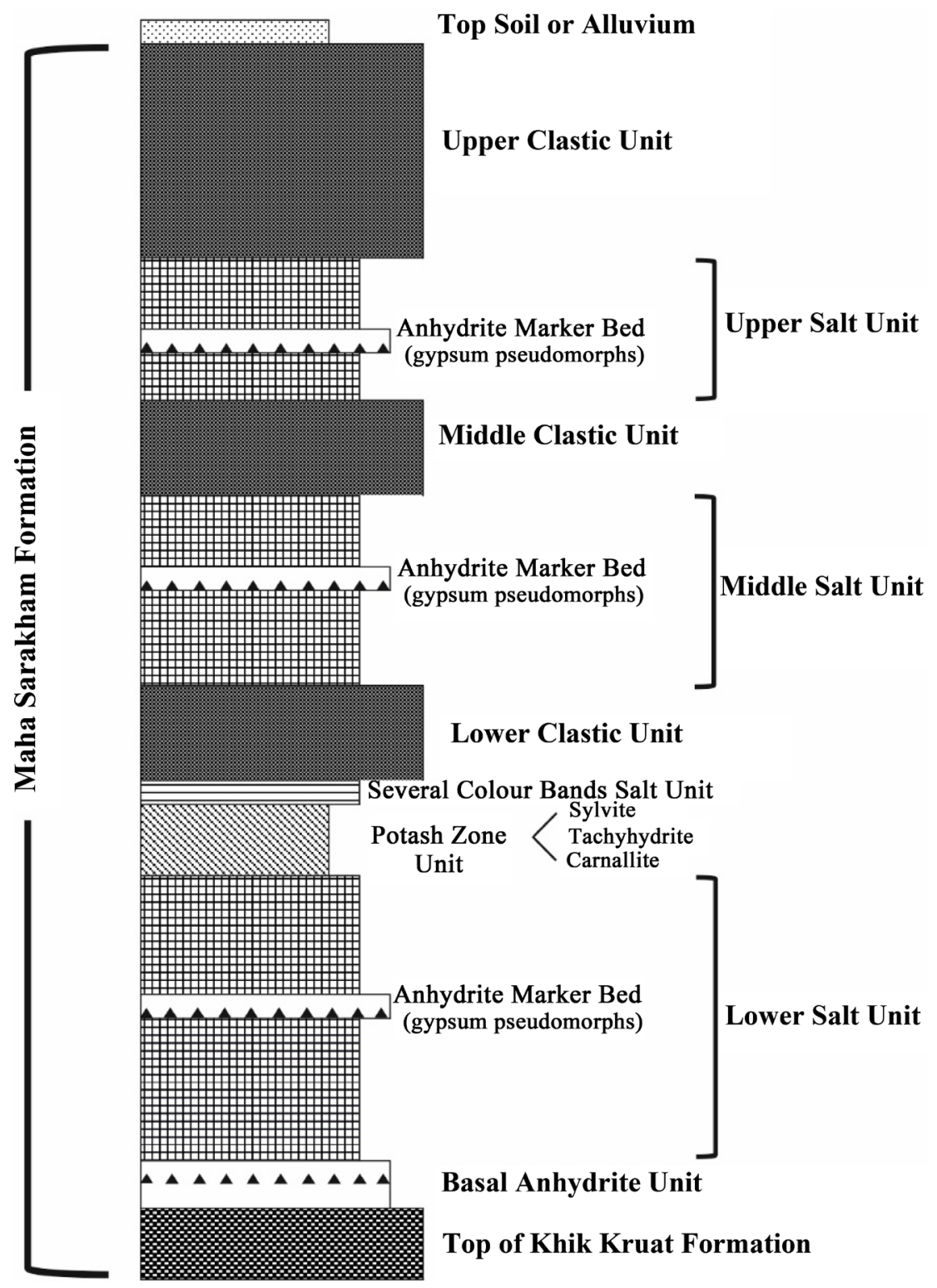

Figure 4. Lithostratigraphy of the complete sedimentary section of the Maha Sarakham Formation. After [16] [24] [29].

composed of potassium and magnesium minerals which appear in single layers and is widely distributed throughout the whole Khorat Plateau [29] [31]. Its thickness and distribution is highly variable and may be due to patchy dissolution, deformation and subordinate depositional differences [16]. The potash minerals include sylvite $(\mathrm{KCl})$, carnallite $\left(\mathrm{MgCl}_{2} \cdot \mathrm{KCl} \cdot 6 \mathrm{H}_{2} \mathrm{O}\right)$ as well as the magnesium mineral tachyhydrite $\left(\mathrm{CaMgCl}_{6} \cdot 12 \mathrm{H}_{2} \mathrm{O}\right)$. [25] found that the sylvite is a secondary deposit derived from leaching of carnallite so that the sylvite follows the carnallite beds in intervals. In contrast, the potash minerals are of primary origin. After [16], the Potash Zone Unit can be divided into three zones: 1) a lower zone consisting of massive halite with traces of red coloured carnallite filling dissolution cavities in halite; 2) a middle zone composed of massive and poorly bedded pale red or colourless carnallite and halite; and 3) an upper sylvite containing halite zones with traces of anhydrite and gypsum pseudomorphs. Each zone grades into the next one. Accessory minerals which are associated with sylvite and halite are borate minerals and these occur either in thin layers in the sylvite beds or as dispersed nodules and grains. The tachyhydrite usually appears as a single bed between the carnallite beds showing a gradational contact. The base of the Potash Zone Unit is defined by the first appearance of carnallite. In general, the thickness is highly variable from 10 to $80 \mathrm{~m}$, in average about $50 \mathrm{~m}$ [16] [29] [31]. 


\subsection{Several Colour Bands Salt Unit}

The Several Colour Bands Salt Unit is a very thin bed deposited on the Potash Zone Unit. It grades into the underlying Potash Zone. It's occurrence may be explained by ground water leaching. It is composed of multi-colour bands of grey, orange, red, honey, colourless and smoky dark halite. Some carnallite and tachyhydrite are also found (for details see [29] [31]).

\subsection{Lower Clastic Unit}

The Lower Clastic Unit is situated between the underlying Potash Zone and the overlying Middle Salt Unit. The rocks are very similar to the following Middle Clastic Unit. Both are semi-consolidated to damp mudstones showing a dissolution contact to the underlying rock unit, but gypsum is absent. The colour of the Lower Clastics is dark-red to reddish-brown but at the base there are locally greenish-grey portions. Carnallite veins and veinlets occur in this unit showing a mostly deep red-orange colour. Its thickness ranges from a few metres up to $70 \mathrm{~m}$ [24] [29] [31].

\subsection{Middle Salt Unit}

The Middle Salt Unit overlies the Lower Clastic Unit and the underlying Middle Clastic Unit. The mean thickness is about 30 - $130 \mathrm{~m}$ [29] [31]. The whole Middle Salt Unit shows most of the depositional and diagenetic features like the Lower Salt Unit. Reference [16] divided this halite unit into two different sequences: the Halite M1 Unit and Halite M2 Unit. They are separated by an anhydrite marker bed. The Halite M1 Unit consists of well-bedded, dark honey coloured halite layers which are interbedded with thin anhydrite beds and layers of gypsum pseudomorphs. Some traces of a few sylvite and carnallite spots are found. The Halite M2 Unit contains dark honey coloured bedded halite, which is interbedded with dark smoky coloured halite beds. Anhydrite stringers and gypsum pseudomorphs are also found.

\subsection{Middle Clastic Unit}

The Middle Clastic Unit overlies the Middle Salt Unit and the underlying Upper Salt Unit. The rocks are predominantly composed of clay, which is mostly dark reddish-brown in colour. In some cases, layers consisting of breccias are found. Furthermore, in some portions calcareous components and gypsum veins as well as veinlets near the bottom occur in this rock stratum [29] [31]. The thickness of this unit ranges between 20 - $70 \mathrm{~m}$ [16]. If no overlying Upper Salt Unit exists, due to dissolution and salt flowage, the Upper Clastic Unit overlies the Middle Clastic Unit directly. The contact of the Middle Clastic Unit with the underlying Middle Salt Unit shows either a sharp or a gradational contact [29] [31].

\subsection{Upper Salt Unit}

The Upper Salt Unit, if not erased through salt structures or dissolution, generally overlies the Middle Clastic Unit and the underlying Upper Clastic Unit. Near the structural high, salt ridges and domes of the Upper Salt are dissolved and destroyed as a result of flowage. The thickness is highly variable and up to $20 \mathrm{~m}$. It is usually composed of moderate to dark yellowish-brown or honey coloured halite, minor anhydrite layers, dark smoky coloured halite bands, milky-white coloured halite and a few orange coloured halite grains. Generally, the characteristics of the Upper Salt Unit are similar to the Middle Salt Unit, but with geochemical methods they can be separated by the KBr content [29] [31]. Several authors like [29] [31] and [16] divided this unit into two sequences: the Halite U1 Unit and Halite U2 Unit. These sequences are separated by an anhydrite marker bed, which is about $1.5 \mathrm{~m}$ in thickness. The Halite U1 Unit forms the contact to the Middle Clastic Unit and is composed of moderate to dark-honey or yellowish-brown coloured halite with minor anhydrite beds and a few layers of gypsum pseudomorphs, whereas the Halite U2 Unit mostly consists of dark-honey and interbedded darksmoky and minor orange coloured halite. Local traces of potash are also found.

\subsection{Upper Clastic Unit}

The Upper Clastic Unit represents the uppermost rock stratum of the Maha Sarakham Formation. The Unit is mostly built up of pale to moderate reddish-brown or brick-red coloured sandstone, siltstone and claystone [29] 
[31]. Cross-beds and well-defined bedding are observable. The thickness is highly variable up to $680 \mathrm{~m}$ [16]. At middle to lower sections white clear gypsum veins and veinlets are found [31]. The contact with the overlying Phu Thok Formation, which is also composed of clastics, is not clearly defined. In comparison, the clastics of the Phu Thok Formation are coarser than the ones of the Upper Clastic Unit.

\subsection{Phu Thok Formation}

The Phu Thok Formation occurs in the northern and central parts of the Khorat Plateau. Its thickness varies between 200 - $350 \mathrm{~m}$. The lower 100 - $200 \mathrm{~m}$ generally consists of a sequence of brick-red to red-brown coloured claystone with minor siltstone and rare fine-grained, thin sandstone beds, whereas the following meters consist of thick beds of brick-red coloured sandstone with cross-bedding. For the lower part of the formation a very lowenergy fluvial system is assumed, while the upper part certainly represents an aeolian environment. The contact with the underlying Maha Sarakham Formation is unconformable. Based on its stratigraphic position, the Phu Thok Formation is considered to be Late Cretaceous in age although some authors have attributed it to the Early Cenozoic, e.g. [12] [30]. For a general stratigraphic correlation and detailed lithological description see also [32].

\section{Sample Locations and Analytical Methods}

The study area is located in the western part of the Khorat Basin on the Khorat Plateau, in northeastern Thailand. In general, the topography of northeastern Thailand consists of rolling plains bounded by mountains to the west and south. The exact working area is situated in a salt mine in Bamnet Narong (Chaiyaphum Province) where mining took place for decades. The samples were collected along a $1200 \mathrm{~m}$ profile in one shaft of the mine. Figure 5(a) shows the surface projection of this shaft with the respective sample points. The samples vary from halite and anhydrite to carnallite and one sample represents an intercalated clay layer from the Middle Clastic Unit. The vertical distribution of these different salt layers within the deposition is shown in the stratigraphic column in Figure 5(b).
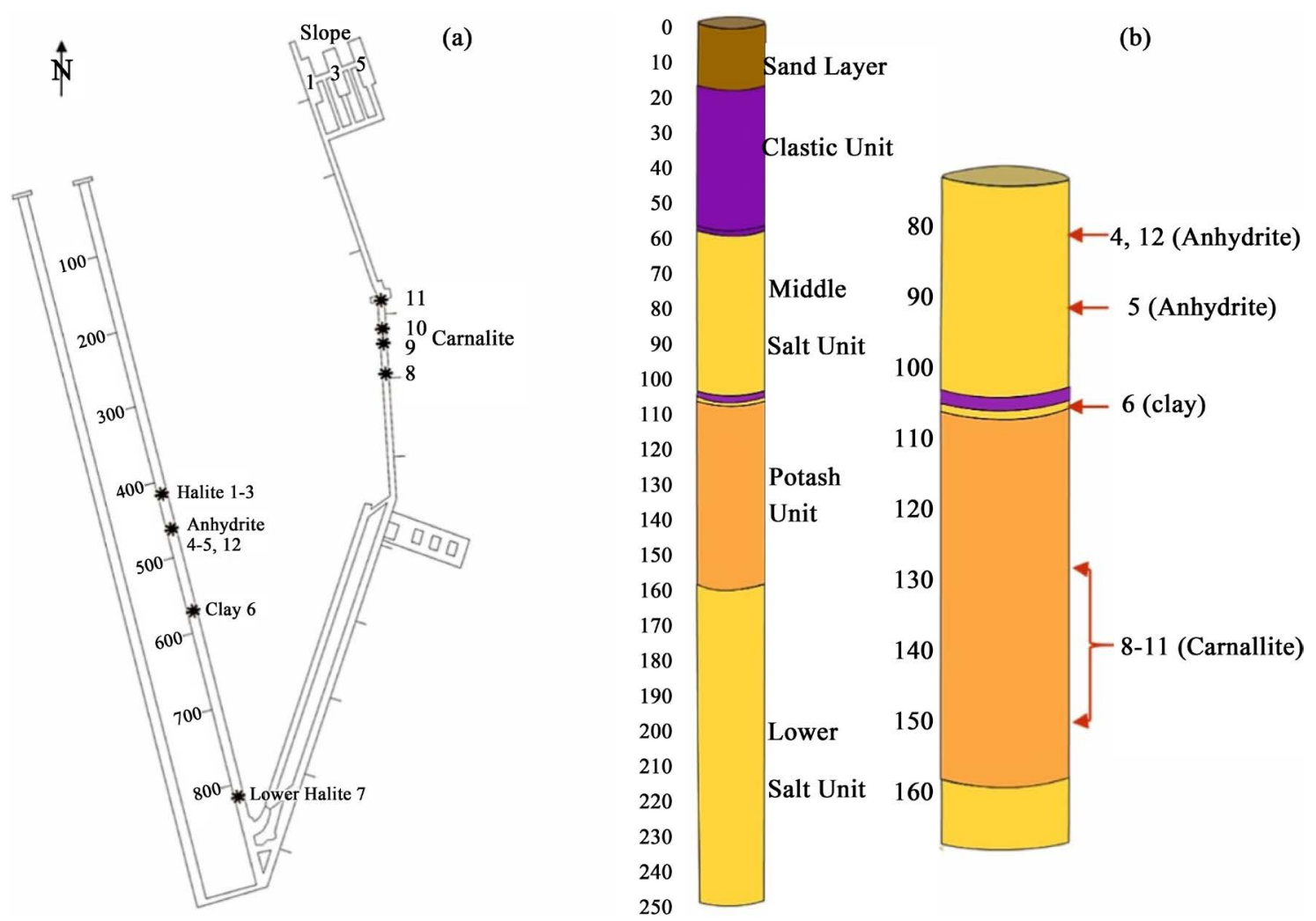

Figure 5. Surface projection of the $1200 \mathrm{~m}$ long shaft (a). The vertical distribution of the different salt layers (core sample) at the right in the diagram. Modified after URL: http://www.apmcnet.com/en/project_bamnet.php (query 20.09.2013). 
Samples collected for rare earth elements were determined by ICP-MS on a PerkinElmer DRC II (Sciex, Canada) at the Department of Geochemistry. Bromide concentration was measured by anion chromatography DX320 (Dionex) with an auto-sampler AS11-HC at the Department of Applied Geology department. Sr concentrations and isotopic compositions were determined using a Thermo-Finnigan Triton ${ }^{\mathcal{C}}$ TIMS at the Department of Isotope Geology. Prior to digestion, samples were mixed with a tracer solution enriched in ${ }^{87} \mathrm{Rb}^{84} \mathrm{Sr}$. Detailed descriptions of the analytical procedure for salt samples is given in [33] and [34]. Throughout this work, a value of $0.710267 \pm 0.000041(2 \sigma)$ for the NBS $987(\mathrm{n}=10)$ was observed. Instrumental mass fractionation was corrected with a ${ }^{88} \mathrm{Sr} /{ }^{86} \mathrm{Sr}$ ratio of 0.1194 using the exponential law. K-Ar analyses were also performed at the Department of Isotope Geology. The analytical procedure is given in [35]. All departments are part of the Geoscience Centre (GZG) at the University of Göttingen (Germany).

\section{Analytical Results}

\section{1. $\mathrm{Rb}-\mathrm{Sr}$ and $\mathrm{Sr}-\mathrm{Sr}$}

Carnallites and anhydrites were analysed for their Rb-Sr values. Table 1 shows these data including the ${ }^{87} \mathrm{Sr} /{ }^{86} \mathrm{Sr}$ ratios corrected to an NBS987 value of 0.71024 used for the calculation of ages by means of the LOWESS Isotopic Database [7] in order to acquire the corresponding age of this stratigraphic unit.

The anhydrite samples are almost free of rubidium, except sample ST12, which in comparison to its strontium content includes more rubidium. Most probably it is not pure anhydrite, which is also recognizable in the plot in Figure 6(a). The ${ }^{87} \mathrm{Sr} /{ }^{86} \mathrm{Sr}$ ratios vary between 0.707461 and 0.707630 . In contrast, the carnallites show a high range of strontium and rubidium content without an obvious trend. The lowest ratio by far is measured in sample ST11 with 0.707881 , and in relation to the other samples, it contains much more strontium in comparison to the amount of rubidium. Generally, the carnallites scatter in the Rb-Sr diagram (Figure 6(b)).

The ${ }^{87} \mathrm{Sr} /{ }^{86} \mathrm{Sr}$ record can be used to date and correlate marine sediments [36]. The change in the marine ${ }^{87} \mathrm{Sr} /{ }^{86} \mathrm{Sr}$ ratio throughout the Phanerozoic is shown Figure 7. For the samples discussed, the Late Cretaceous

\section{Table 1. Rb-Sr Data.}

\begin{tabular}{ccccccccc}
\hline Sample & $\begin{array}{c}{ }^{86} \mathrm{Sr} \\
(\mu \mathrm{mol})\end{array}$ & $\begin{array}{c}\mathrm{Sr} \\
(\mu \mathrm{g} / \mathrm{g})\end{array}$ & $\begin{array}{c}{ }^{87} \mathrm{Rb} \\
(\mu \mathrm{mol})\end{array}$ & $\begin{array}{c}\mathrm{Rb} \\
(\mu \mathrm{g} / \mathrm{g})\end{array}$ & ${ }^{87} \mathrm{Rb} /{ }^{86} \mathrm{Sr}$ & ${ }^{87} \mathrm{Sr} /{ }^{86} \mathrm{Sr}[\mathrm{fc}]$ & $2 \mathrm{se}$ & $\begin{array}{c}{ }^{87} \mathrm{Sr} /{ }^{86} \mathrm{Sr}[\mathrm{fc}] \\
\text { corrected }\end{array}$ \\
\hline Anhydrite ST4 & 0.024124 & 410.7 & 0.00019 & 1.12 & 0.007825 & 0.707595 & 0.000016 & 0.707595 \\
Anhydrite ST5 & 0.030156 & 475.0 & 0.00017 & 1.01 & 0.005497 & 0.707484 & 0.000019 & 0.707461 \\
AnhydritST12 & 0.001302 & 23.1 & 0.00007 & 0.463 & 0.057561 & 0.707653 & 0.000044 & 0.707630 \\
Carnallite ST11 & 0.015876 & 284.0 & 69.8 & 69.8 & 0.706835 & 0.707904 & 0.000017 & 0.707881 \\
Carnallite ST10 & 0.002626 & 46.8 & 53.0 & 53.0 & 3.230726 & 0.709293 & 0.000013 & 0.709270 \\
Carnallite ST9 & 0.002016 & 35.7 & 60.6 & 60.6 & 4.886292 & 0.709171 & 0.000047 & 0.709148 \\
Carnallite ST8 & 0.002483 & 43.9 & 45.6 & 45.6 & 2.986739 & 0.709636 & 0.000130 & 0.709613 \\
\hline
\end{tabular}

fc. = ratio corrected for mass fractionation, corr. = ratio downscaled to an NBS987 value of 0.71024 .
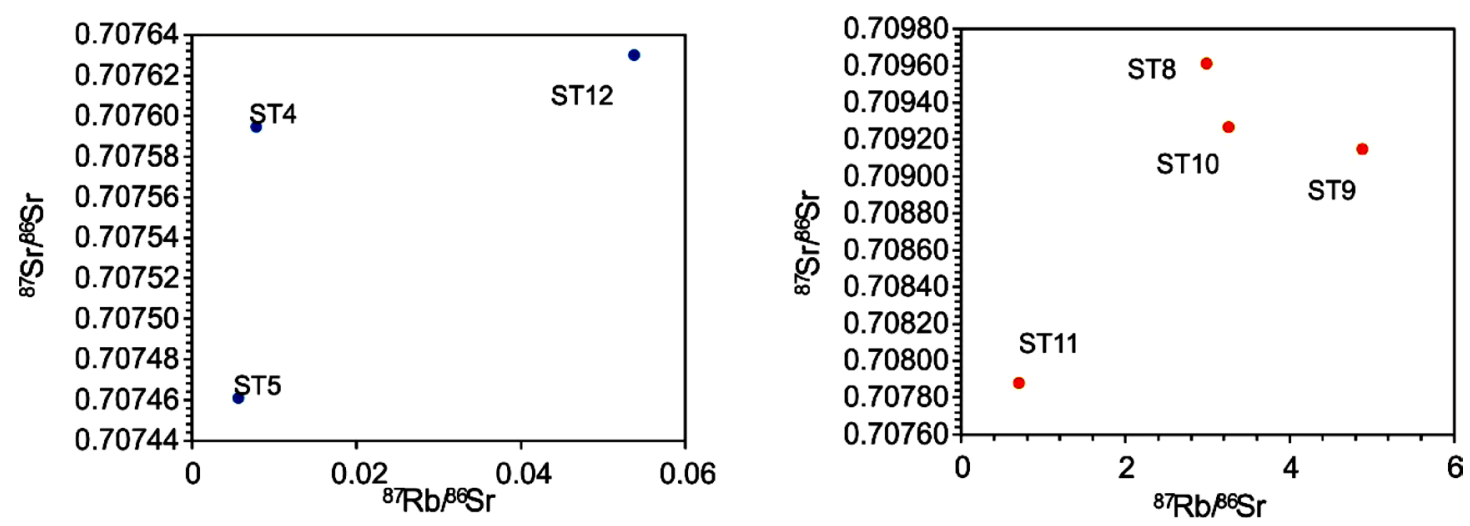

Figure 6. Rb-Sr-Plot of the anhydrites (a) and the carnallites (b). 

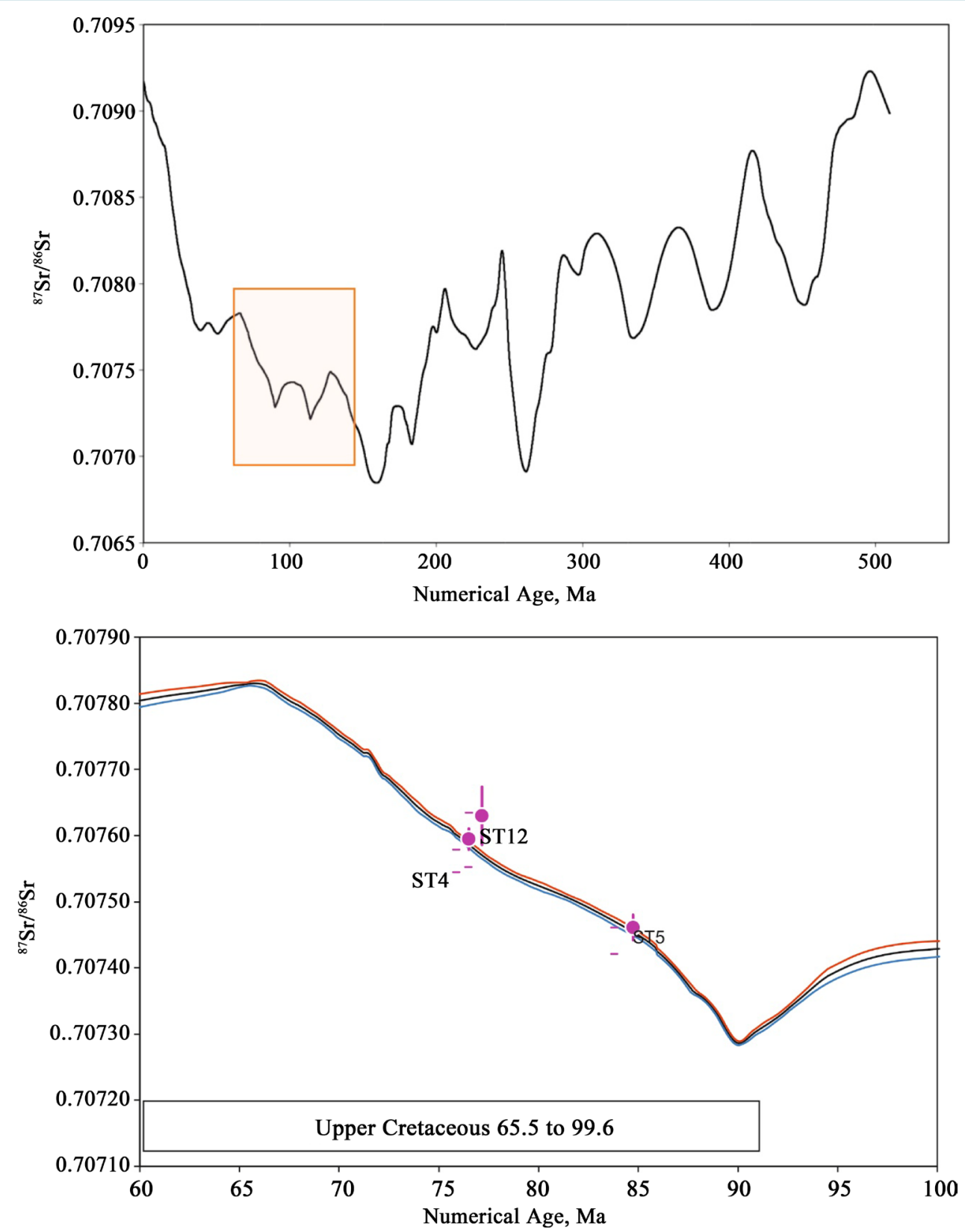

Figure 7. Sea water evolution curve, LOWESS, during the Phanerozoic with a more detailed section of the Cretaceous after [7]. Red coloured line means the upper limit of the ${ }^{87} \mathrm{Sr} /{ }^{86} \mathrm{Sr}$, the blue one analogues the lower limit and the black curve is the mean value.

time is important and needs to be looked at in more detail because of the stratigraphic relation of the formations. Details on how the LOWESS fit is derived are given in [36]. To determine the age by using the LOWESS fit, it is necessary to calculate the initial ${ }^{87} \mathrm{Sr} /{ }^{86} \mathrm{Sr}$ ratio for different ages by correcting for the amount of ${ }^{87} \mathrm{Sr}$ enrichment by ${ }^{87} \mathrm{Rb}$ decay. Is the initial value equal to the seewater curve, which is used for the calculation, then this is the age of the sample. This was done for all the anhydrites as well as for all the carnallites.

This method was not applicable for the carnallites due to their high contents of rubidium. The back-calculated initials for $95 \mathrm{Ma}$ are extremely low (0.70256 - 0.70694), which would normally reflect a strong input of volcanic material into the basin. This cannot be true as the basin was filled from the west and the only volcanic material present crops out in the south and is Cenozoic in age. By plotting the ${ }^{87} \mathrm{Sr} /{ }^{86} \mathrm{Sr}$ ratios of the anhydrites against the so-called LOWESS composite strontium isotope curve from [7], the authors fit the curve with limits 
of error corresponding to ages of the Upper Cretaceous. This was a period of worldwide sea level change (transgression) [37].

\subsection{K-Ca age Determination}

Carnallite is an evaporitic double chloride mineral, a hydrated potassium magnesium chloride with the chemical formula: $\mathrm{KMgCl}_{3} \cdot 6\left(\mathrm{H}_{2} \mathrm{O}\right)$. It occurs within a sequence of potassium and magnesium evaporate minerals such as sylvite and kainite, and other salts like gypsum and anhydrite. Since this mineral is theoretically free of calcium, it should be possible to date these evaporates by means of the K-Ca method.

Four carnallites samples (Figure 5) have been analysed (Table 2 \& Table 3) concerning their calcium and potassium content for the K-Ca age determination. Because of the immobility of calcium and its characteristic as a retentive daughter, the K-Ca ages are more resistant to resetting. However, in this case it turned out that the analysed samples (after loss of ignition) were inhomogeneous even on a small scale, and thus analytical results of the Ca-concentration could not be reproduced. To find out whether the calcium determinations are influenced by a possible heterogeneity of the salt, the sample ST11 was used to investigate each clearly recognisable phase of carnallite separately (in the rock association, Figure 8). This figure shows the hand-specimen of sample ST11 (a) and the parts (b)-(d), which were differentiated on the basis of their colour difference and then crushed in a mortar. The optical inhomogeneity was confirmed by LA-ICPMS investigations. The carnallites were analysed for their $\mathrm{Li}, \mathrm{B}, \mathrm{Na}, \mathrm{Mg}, \mathrm{Al}, \mathrm{Si}, \mathrm{S}, \mathrm{Cl}, \mathrm{K}, \mathrm{Ca}, \mathrm{Mn}, \mathrm{Br}, \mathrm{Rb}, \mathrm{Sr}, \mathrm{Cs}$ and $\mathrm{Pb}$ content by profiles on different fragments of the salts. Iron was not measured because it behaves like manganese. The profiles vary in length from 1 - $2.5 \mathrm{~mm}$, since the length is correlated to the time in seconds, this is indicated as a reference. For these measurements the total magnesium amount was set to $400,000 \mathrm{ppm}$, and therefore it calculates everything in relation to it. This was later relativized during the normalisation. One encountered problem was that chlorine was immensely mobile during the measurement and shows a strong drift, so that the published values in ppm are incorrect as an absolute value. They are still relative if the proportions or ratios are considered, and for the change over time on a logarithmic scale. We here just show the most meaningful elevated ones (Figures 9-11). Sample ST8 was measured four times. The samples are all similar, therefore only some spectra from ST11 are given below. Apparently there are abrupt changes concerning the content of magnesium and potassium over four magnitudes (Figure 9) or the content of both elements can be constant along the profile. Again it can be seen that both magnesium and potassium can behave in the same way, but also contrary to each other (Figure 9(c) \& Figure $9(d)$ ). These changes in the concentration occur very suddenly and unexpectedly, which indicate different phases in the carnallite.

Table 2. Results of the LOWESS fit after [7] for all samples.

\begin{tabular}{ccccccccccc}
\hline A & ${ }^{87} \mathrm{Rb} /{ }^{86} \mathrm{Sr}$ & ${ }^{87} \mathrm{Sr} /{ }^{86} \mathrm{Sr}_{\text {corr }}$ & Ini.75 Ma. & Mean & Ini.76 Ma. & Mean & Ini.77 Ma. & Mean & Ini.78 Ma. & Mean \\
\hline ST4 & 0.007825 & 0.707595 & 0.707586 & 76.5 & 0.707586 & 76.5 & 0.707586 & 76.5 & 0.707586 & 76.5 \\
ST12 & 0.053763 & 0.707630 & 0.707573 & 77.05 & 0.707572 & 77.10 & 0.707571 & 77.15 & 0.707571 & 77.15 \\
ST5 & 0.005637 & 0.707661 & 0.707461 & 84.70 & 0.707455 & 84.70 & 0.707455 & 84.70 & 0.707455 & 84.7 \\
ST11 & 0.706835 & 0.707881 & 0.707128 & 147,85 & 0.707118 & 148.20 & 0.707108 & 148.50 & 0.707098 & 148.85 \\
ST10 & 3.230726 & 0.709270 & 0.705798 & - & 0.705752 & - & 0.705706 & - & 0.705660 & - \\
ST9 & 4.886292 & 0.709148 & 0.703945 & - & 0.703875 & - & 0.703806 & - & 0.703736 & - \\
ST8 & 2.986739 & 0.709613 & 0.706430 & - & 0.706388 & - & 0.706346 & - & 0.706303 & - \\
\hline B & ${ }^{87} \mathrm{Rb} /{ }^{86} \mathrm{Sr}$ & ${ }^{87} \mathrm{Sr}^{86} \mathrm{Sr}_{\text {corr }}$ & Ini.84 Ma & Mean & Ini.85 Ma. & Mean & Ini.86 Ma & Mean & Ini.100 Ma. & Mean \\
\hline ST4 & 0.007825 & 0.707595 & 0.707585 & 76.55 & 0.707585 & 76.55 & .707585 & 76.55 & 0.706878 & 76.60 \\
ST12 & 0.053763 & 0.707630 & 0.707566 & 77.35 & 0.707566 & 77.35 & 0.707564 & 77.45 & 0.707554 & 77.95 \\
ST5 & 0.005637 & 0.707661 & 0.707454 & 84.75 & 0.707454 & 84.75 & 0.707454 & 84.75 & 0.707453 & 84.8 \\
ST11 & 0.706835 & 0.707881 & 0.707038 & 150.60 & 0.707038 & 150.60 & 0.707018 & 151.10 & 0.706878 & 155.20 \\
T10 & 3.230726 & 0.709270 & 0.705382 & - & 0.705382 & - & 0.705289 & - & 0.704641 & - \\
ST9 & 4.886292 & 0.709148 & 0.703320 & - & 0.703320 & - & 0.703181 & - & 0.702210 & - \\
ST8 & 2.986739 & 0.709613 & 0.706049 & - & 0.706049 & - & 0.705964 & - & 0.705370 & - \\
\hline
\end{tabular}




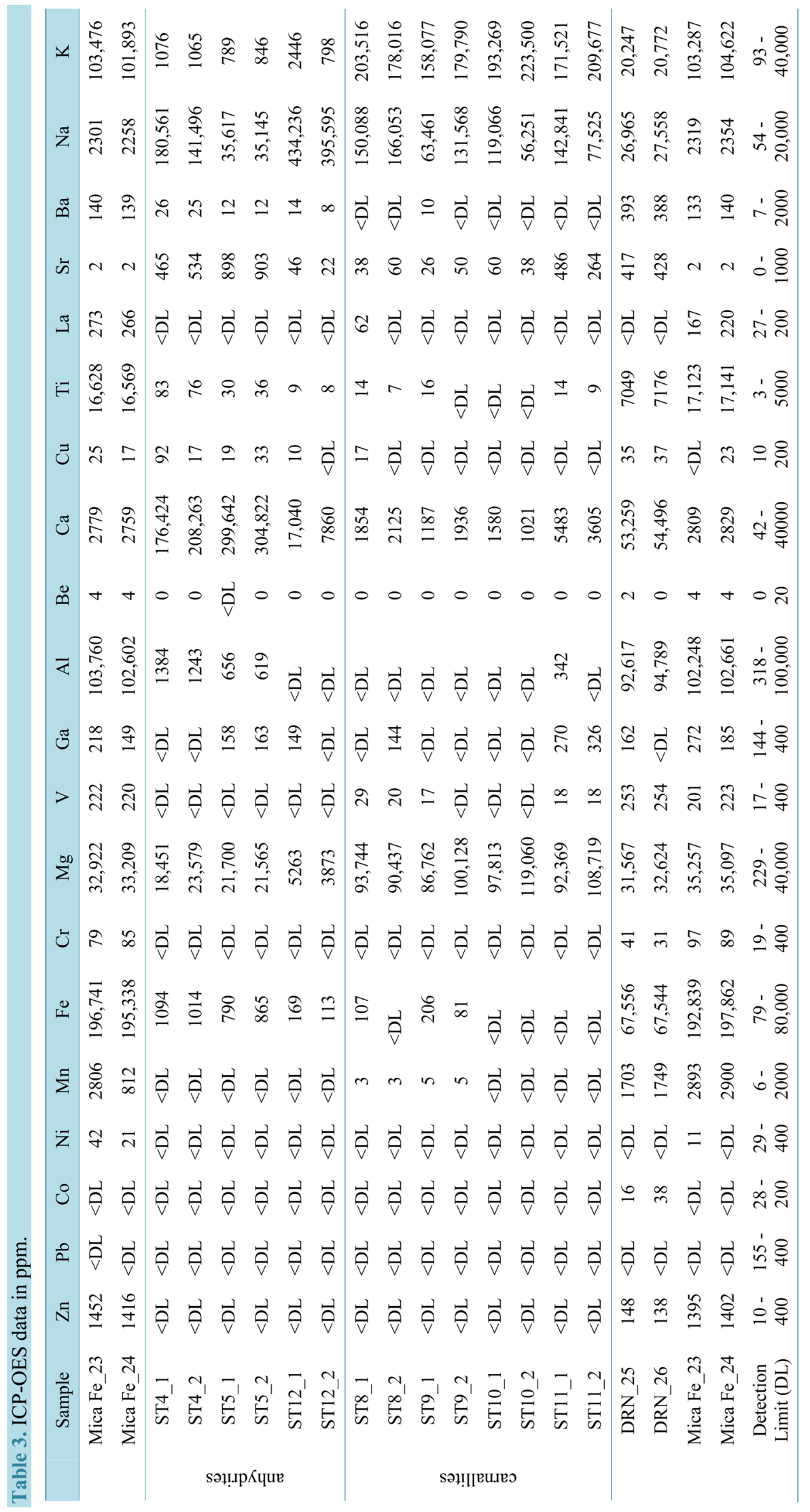



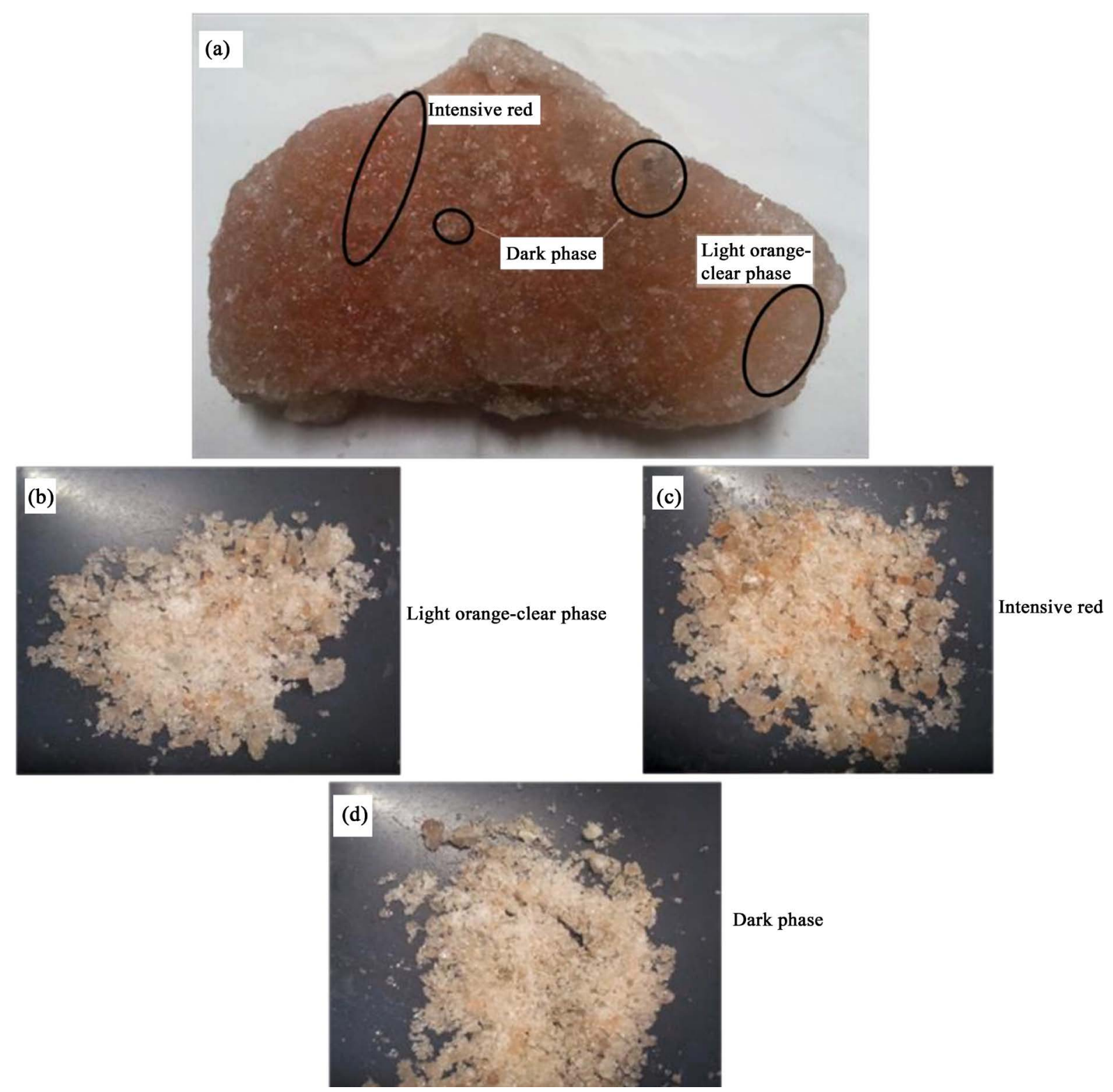

Figure 8. Pictures of sample ST11 and different portions of it. (a) The base material of sample ST11 with different phases highlighted; (b) Light orange-clear phase, crushed; (c) Intensive red phase, crushed; (d) Dark phase, crushed (in the rock association this phase was much darker than it appears in the picture).

Overall, sample ST11 is mostly subject to fluctuations in terms of the various measured elements. The changes of the elements manganese, sodium and calcium can be seen in the graphs of Figure 10. Sodium generally shows the strongest variations with respect to the changing high of magnitude. Compared with Figure 9, the sodium content always increases abruptly when the potassium and magnesium content decreases but with one exception: In part $\mathrm{C}$ of both figures the content of sodium increases immensely after about 235 seconds, while the potassium and magnesium content only shows a little change or fluctuation. Calcium itself also varies greatly, especially at points of increasing sodium content. In contrast to the change of the magnesium and potassium content the calcium content remains unchanged. The boron content in the carnallite varies strongly over four orders of magnitude, as shown in Figure 11. Furthermore, it is evident that each portion of the carnallite sample contains boron (B). The recognisable peaks of the boron content are in favour of a boron-containing phase, as already mentioned above. In a $\mathrm{Rb} / \mathrm{Br}$ diagram [38], the obtained ratios plot outside the field of primary carnallites except sample ST9 (Figure 12). Based on the facts presented, a dating of the investigated carnallites 

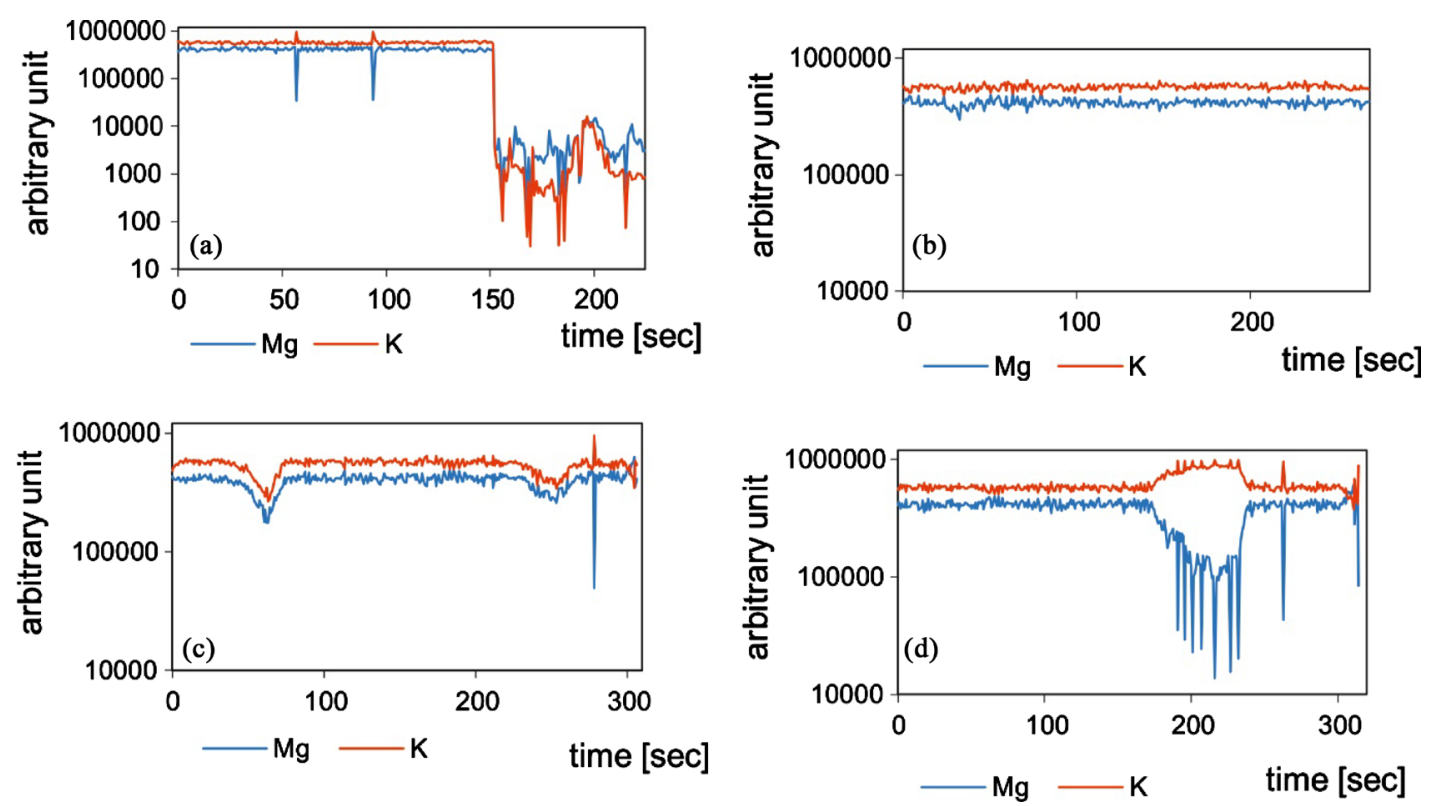

Figure 9. Mg and K results (using LA-ICPMS) of sample ST11with different measurements for different portions of the sample.
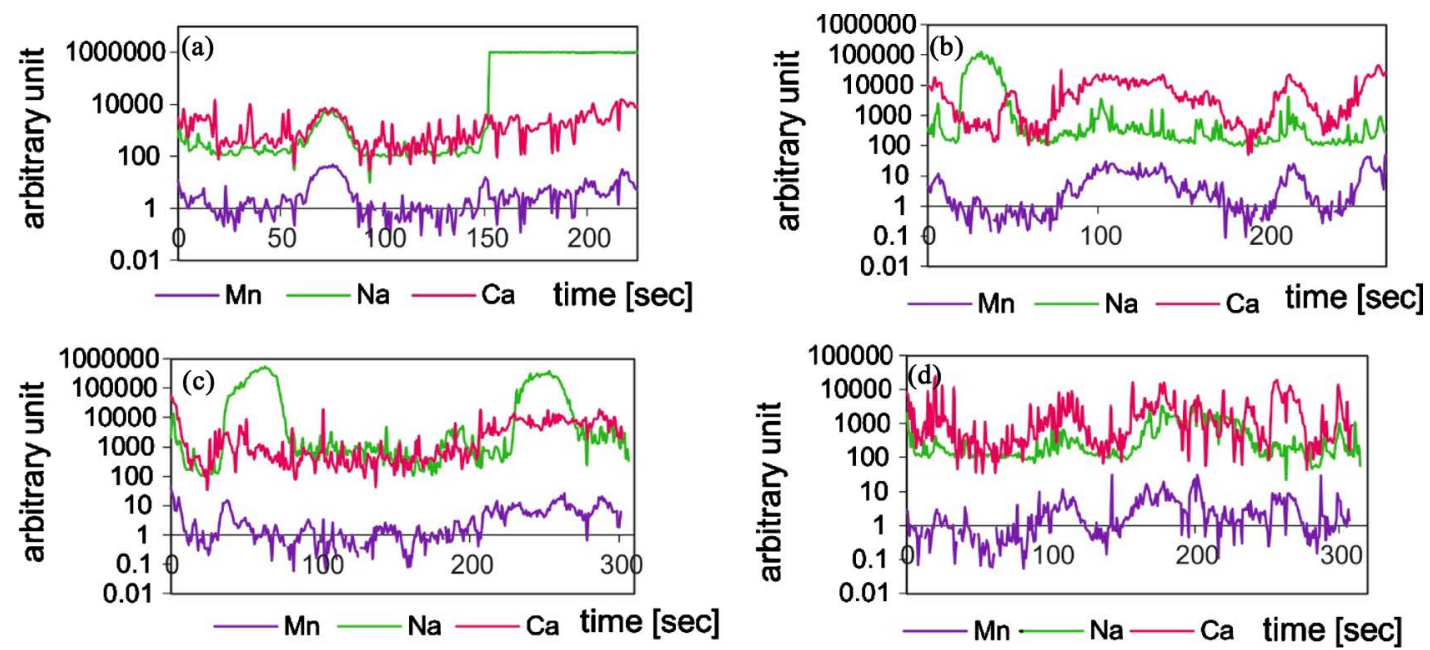

Figure 10. Mn, Na and Ca results (using LA-ICPMS) of sample ST11 with different measurements for different portions of the sample.

is not possible due to the inhomogeneity of the samples,. An attempt to have a more representative sample by using higher sample amounts failed due to the high concentration of sodium. The fact that the analysed samples do not originate from primary carnallite is confirmed by separate $\mathrm{Br}$ analyses (Table 4). If these data are plotted against the concentration of $\mathrm{Rb}$ in a $\mathrm{Rb} / \mathrm{Br}$ diagram [38], therefore also $\mathrm{K}$ was redistributed during later hydrothermal activity.

\subsection{K-Ar}

In 2002 the authors in [5] presented a K-Ar age for the clay layer in between the Middle Salt Unit and the Potash Unit (Figure 5) of 97.7 Ma. The analytical data are given in Table 4. The age was obtained in the fraction $<0.2$ $\mu \mathrm{m}$. The illite crystallinity of the sample corresponds to a Kübler Index (KI) of $0.69 \Delta^{\circ} 2 \Theta$. This value is normally interpreted as reflecting diagenetic conditions. However, we cannot exclude that the sample contains tiny parts of detrital material, so therefore we interpret this age as a maximum age for the deposition of the clay Table 5. 

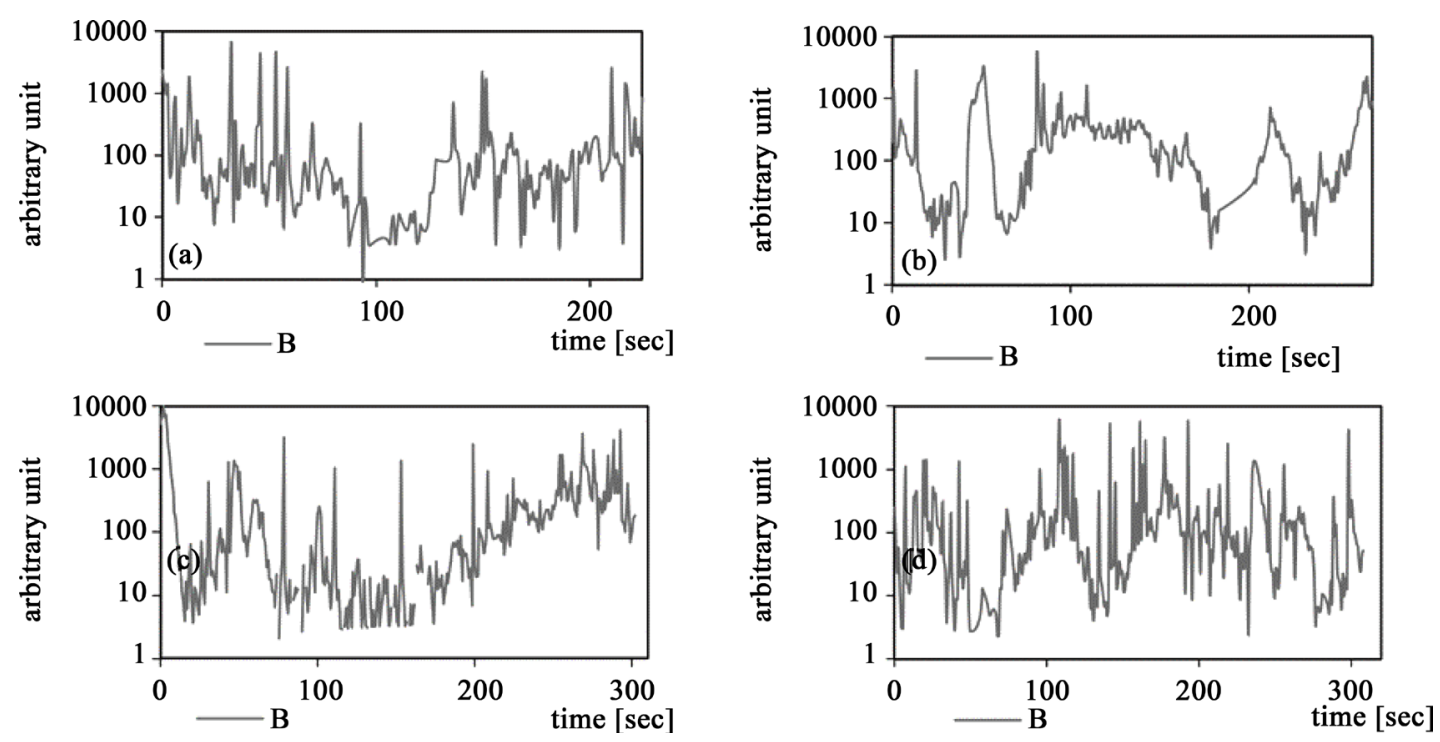

Figure 11. Boron results (using LA-ICPMS) of sample ST11 with different measurements for different portions of the sample.

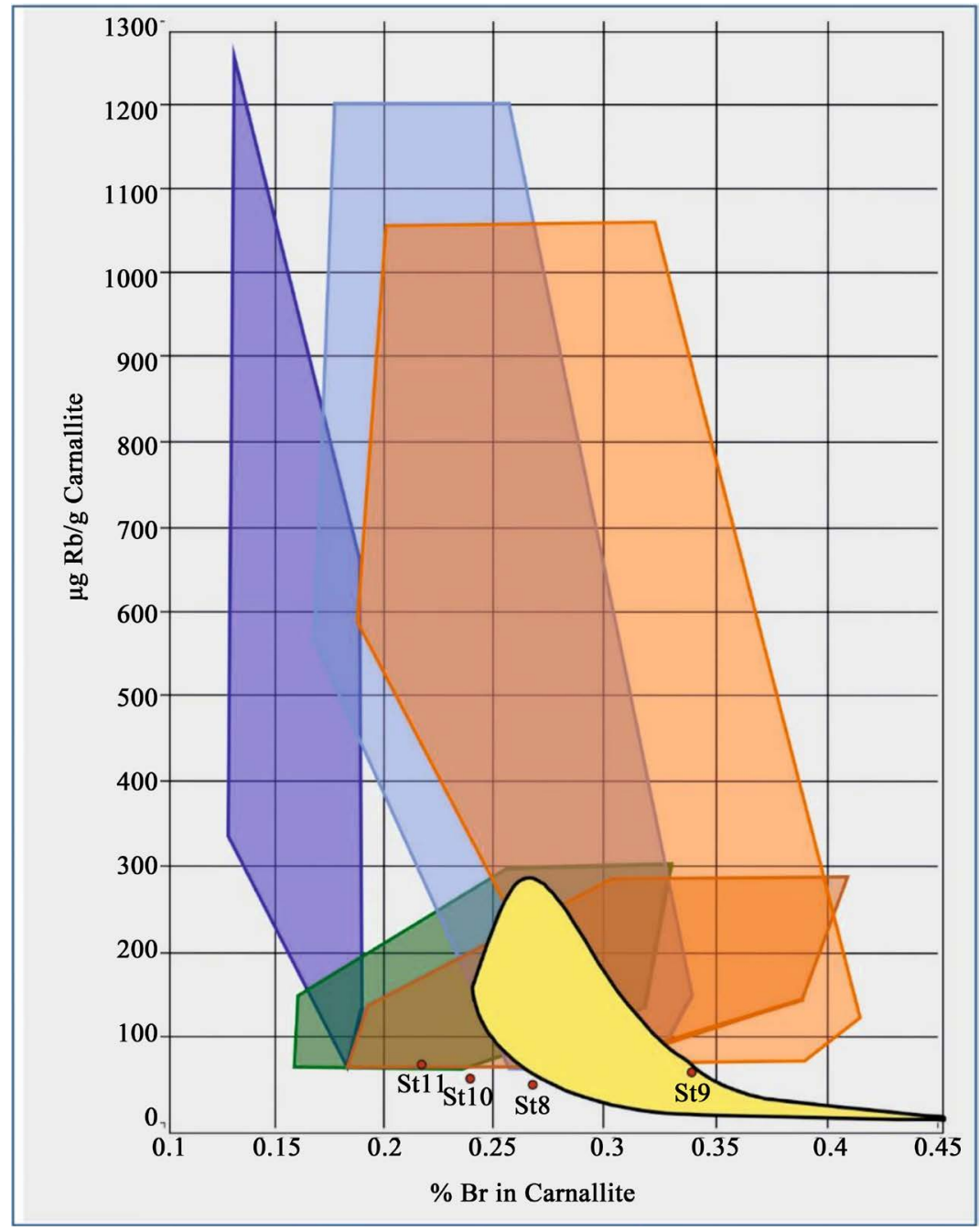

Figure 12. Rb distribution in primary carnallite (yellow area) after [38]. 
Table 4. Bromide content.

\begin{tabular}{ccc}
\hline Sample No. & Bromide in \% & Bromide mean $\%$ \\
\hline ST8 & 0.268 & 0.268 \\
ST8 & 0.268 & \\
ST9 & 0.342 & 0.340 \\
ST9 & 0.339 & \\
ST10 & 0.238 & 0.239 \\
ST10 & 0.241 & \\
ST11 & 0.217 & 0.217 \\
ST11 & 0.217 & \\
\hline
\end{tabular}

Table 5. K-Ar analytical data from clay sample ST6.

\begin{tabular}{ccccccc}
\hline Sample No ST 6 & $\mathrm{~K}_{2} \mathrm{O}(\mathrm{Wt} . \%)$ & ${ }^{40} \mathrm{Ar}^{*}(\mathrm{nl} / \mathrm{g}) \mathrm{STP}$ & ${ }^{40} \mathrm{Ar}^{*}(\%)$ & Age $(\mathrm{Ma})$ & $2 \sigma$-Error $(\mathrm{Ma})$ & Illite crystallinity $\Delta^{\circ} 2 \Theta$ \\
\hline$<0.2 \mu \mathrm{m}$ & 6.12 & 18.98 & 78.99 & 93.7 & 2.7 & 0.69 \\
\hline
\end{tabular}

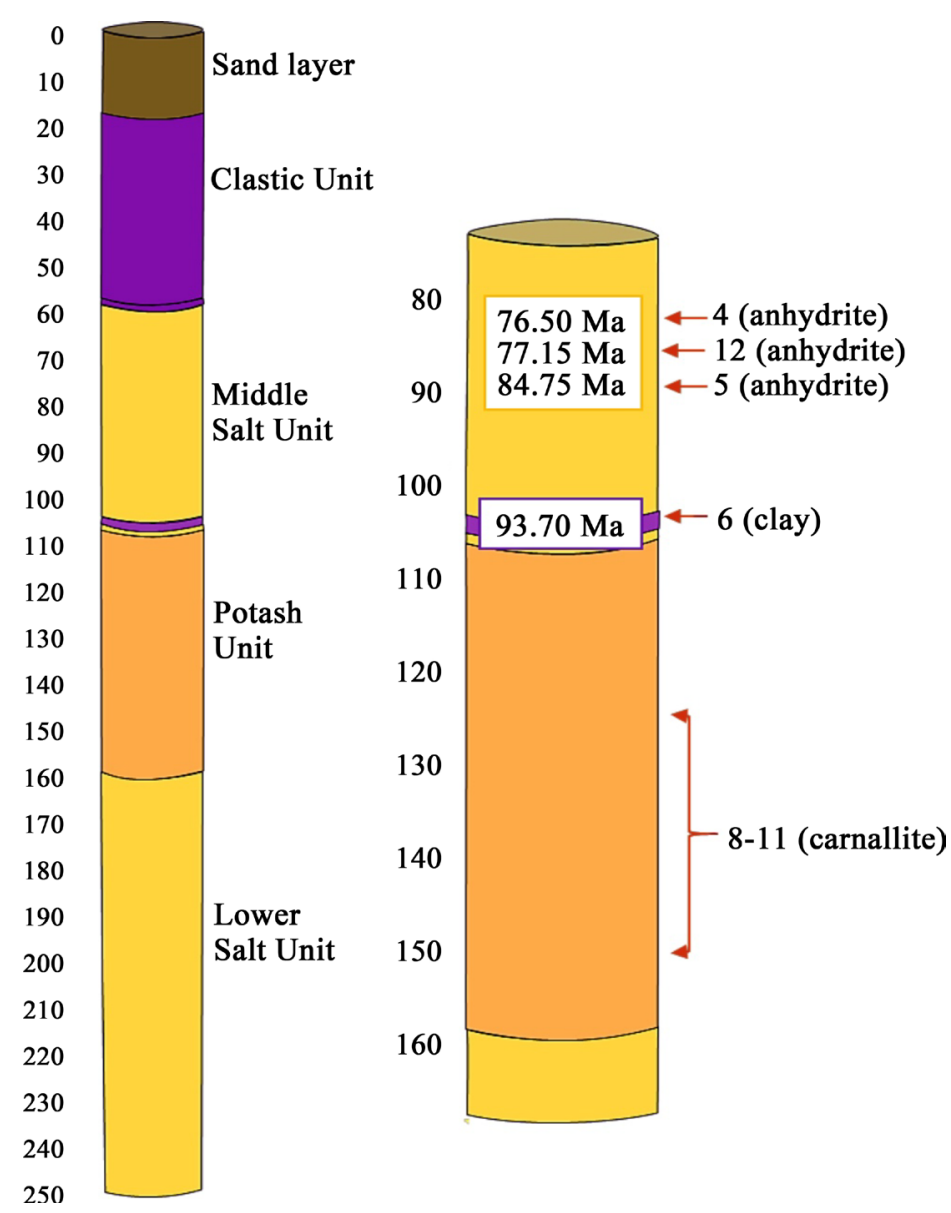

Figure 13. Vertical distribution of the different salt layers (core sample) with the data points and the obtained depositional ages.

\section{Discussion and Conclusions}

The age of the salt in Bamnet Narong has been debated since the late 1970's by using multiple stratigraphic and isotopic approaches. The goal of the present study was to obtain age data, particularly for the carnallites by using the K-Ca as well as the Rb-Sr decay. However, as discussed above the content of calcium is very inhomogeneous, and could therefore not be used for the age determinations. In the Rb-Sr isochrones diagram the carnallite samples scatter, therefore their isotope systems obviously are disturbed by later redistribution of rubidium 
and correspondingly potassium. The K-Br analysis of [39] corresponds with this assumption of redistribution. A possible dissolution of the carnallites effected by groundwater would increase the rubidium content in the solution, the result would be a phase with high ${ }^{87} \mathrm{Sr} /{ }^{86} \mathrm{Sr}$.

The obtained ${ }^{87} \mathrm{Sr} /{ }^{86} \mathrm{Sr}$ data indicates a deposition age for the anhydrites (using the LOWESS fit after [36]) to be between $76.50 \mathrm{Ma}$ and $84.75 \mathrm{Ma}$. Figure 13 illustrates that these ages match the stratigraphy of the Asian Potash Mine as well as the K-Ar age of the clay layer, which represents the Lower Clastic Unit [5]. The age of the Clastic Unit has to be treated with caution because these clastics are erosional continental deposits, so they normally have to be older than the deposition in the basin. The age of the anhydrites of the Middle Salt Unit from the Maha Sarakham Formation is considered to be Santonian to Campanian (Upper Cretaceous). If the age of the clay layer is correct, it indicates that the underlying Potash Unit (carnallites) is at least Cenomanian in age. This would be in good agreement with the obtained ages from [6] who postulated, that the Khok Kruat Formation (which underlies the Maha Sarakham Formation) is of Aptian to Albian age.

\section{Acknowledgements}

We would like to thank the Open Access Publication Fund of the University of Göttingen for their financial support. We are grateful to C. Gross who greatly helped to improve the English text. We also appreciate the help and advice we received in the laboratory by S. Pawlig, N. Nolte, S. Metje, K. Simon, M. Rittmeier and Brigitte Dietrich (all GZG, Göttingen).

\section{References}

[1] Gardner, L.S. and Hayworth, P.N. (1967) Salt Resources of Thailand, Report of Investigation No.11. Department of Mineral Resources, Bangkok, Thailand, 100 p.

[2] Harris Jr., R.W. (1977) Palynological Analyses of Outcrop and Well Samples from the Khorat Basin, Central Thailand. Mineral Fuels Division.

[3] Sattayarak, N. and Polachan, S. (1990) Rock Salt Beneath the Khorat Plateau. Proceedings on Mineral Management, Department of Mineral Resources, Bangkok, 2-6 July 1990, 1-14.

[4] Pisuth-Arnond, V., Chiba, H. and Yamuang, S. (1986) A Preliminary Sulphur and Oxygen Isotope Study of the Maha Sarakham Evaporitic Anhydrite from the Bamnet Narong Area of Northeastern Thailand. Bulletin of the Geological Society of Malaysia, 19, 209-233.

[5] Hansen, B.T., Wemmer, K., Pawlig, S., Klaus, J., Assavapatchara, S. and Nontaso, M. (2002) Isotopic Evidence for a Late Cretaceous Age of the Potash and Rock Salt Deposit at Bamnet Narong, NE-Thailand. Proceedings of the Symposium on the Geology of Thailand, Department of Mineral Resources, Bangkok, 26-31 August 2002, 26-31.

[6] Buffetaut, E. and Ingavat, R. (1986) The Succession of Vertebrate Faunas in the Continental Mesozoic of Thailand. Bulletin of the Geological Society of Malaysia, 19, 167-172.

[7] McArthur, J.M., Howarth, R.J. and Shields, G.A. (2012) Strontium Isotope Stratigraphy. In: Gredstein, F.M., Ogg, J.G., Schmotz, M.D. and Ogg, G.M., Eds., A Geologic Time Scale, Elsevier, Amsterdam, 127-144. http://dx.doi.org/10.1016/b978-0-444-59425-9.00007-x

[8] Suwanich, P. (1986) Potash and Rock Salt in Thailand. Nonmetallic Minerals Bulletin NO. 2, Economic Geology Division, Department of Mineral Resources Bangkok, Thailand, 339 p.

[9] Wannakomol, A. (2005) Soil and Groundwater Salinization Problems in the Khorat Plateau, NE Thailand-Integrated Study of Remote Sensing, Geophysical and Field Data. Dissertation an der Freien Universität Berlin, 205 p.

[10] Zhang, X., Ma, H., Ma, Y., Tnag, Q. and Yuan, X. (2013) Origin of the Late Cretaceous Potash-Bearing Evaporites in the Vientiane Basin of Laos: $\delta 11 B$ Evidence from Borates. Journal of Asian Earth Sciences, 62, 812-818. http://dx.doi.org/10.1016/j.jseaes.2012.11.036

[11] Piyasin, S. (1995) The Hydrocarbon Potential of Khorat Plateau. Proceedings of the International Conference on Geology, Geotechnology and Mineral Resources of Indochina, Khon Kaen University, Khon Kaen, 22-25 November 1995, 551-562.

[12] Meesook, A. (2011) Cretaceous. In: Ridd, M.F., Barber, A.J. and Crow, M.J, Eds., The Geology of Thailand, Geological Society, London, 169-184.

[13] Cooper, M.A., Herbert, R. and Hill, G.S. (1989) The Structural Evolution of Triassic Intermontane Basins in Northeastern Thailand. Proceedings of the International Symposium on Intermontane Basins: Geology and Resources, Chiang Mai, 30 January-2 February 1989, 231-242.

[14] Chonglakmani, C. (2011) Trias. In: Ridd, M.F., Barber, A.J. and Crow, M.J., Eds., The Geology of Thailand, Geologi- 
cal Society, London, 137-150.

[15] Racey, A. and Goodall, J.G.S. (2009) Palynology and Stratigraphy of the Mesozoic Khorat Group Red Bed Sequences from Thailand. Geological Society, London, Special Publications, 315, 69-83. http://dx.doi.org/10.1144/SP315.6

[16] Tabakh, M.E., Utha-Aroon, C. and Schreiber, B.C. (1999) Sedimentology of the Cretaceous Maha Sarakham Evaporates in the Khorat Plateau of Northeastern Thailand. Sedimentary Geology, 123, 31-62. http://dx.doi.org/10.1016/S0037-0738(98)00083-9

[17] Satarugsa, P., Youngmee, W. and Meesawat, S. (2005) New Regional Boundary of Maha Sarakham Formation in the Northeastern Thailand: Results from 2D Seismic Mapping. International Conference on Geology, Geotechnology and Mineral Resources of Indochina (GEOINDO 2005), Khon Kaen, 28-30 November 2005, 212-220.

[18] Ridd, M.F., Barber, A.J. and Crow, M.J. (2011) Introduction to the Geology of Thailand. In: Ridd, M.F., Barber, A.J. and Crow, M.J., Eds., The Geology of Thailand, Geological Society, London, 1-18.

[19] Philippe, M., Suteethorn, V., Lutat, P., Buffetaut, E., Cavin, L., Cuny, G. and Barale, G. (2004) Stratigraphical and Palaeobiogeographical Significance of Fossil Wood from the Mesozoic Khorat Group of Thailand. Geological Magazine, 141, 319-328. http://dx.doi.org/10.1017/S0016756803008604

[20] Heggemann, H., Kohring, R. and Schlüter, T. (1990) Fossil Plants and Arthropods from the Phra Wihan Formation, Presumably Middle Jurassic of Northern Thailand. Alcheringa, 14, 311-316. http://dx.doi.org/10.1080/03115519008619061

[21] Buffetaut, E., Cuny, G., Le Loeuff, J. and Suteethorn, V. (2009) Late Palaeozoic and Mesozoic Continental Ecosystems of SE Asia: An Introduction. Geological Society, London, Special Publications, 315, 1-5. http://dx.doi.org/10.1144/sp315.1

[22] Hahn, L. (1982) Stratigraphy and Marine Ingressions of the Mesozoic Khorat Group in Northeastern Thailand. Geologisches Jahrbuch, Reihe B, 43, 7-35.

[23] Racey, A., Love, M.A., Canham, A.C., Goodall, J.G.S. and Polachan, S. (1996) Stratigraphy and Reservoir Potential of the Mesozoic Khorat Group, North Eastern Thailand: Part 1, Stratigraphy and Sedimentary Evolution. Journal of Petroleum Geology, 18, 5-39. http://dx.doi.org/10.1111/j.1747-5457.1996.tb00511.x

[24] Utha-Aroon, C. (1993) Continental Origin of the Maha Sarakham Evaporates, Northeastern Thailand. Journal of Southeast Asian Earth Sciences, 8, 193-203. http://dx.doi.org/10.1016/0743-9547(93)90021-G

[25] Hite, R.J. and Japakasetr, T. (1979) Potash Deposits of the Khorat Plateau, Thailand and Laos. Economic Geology, 74, 448-458. http://dx.doi.org/10.2113/gsecongeo.74.2.448

[26] Sattayarak, N., Srikulwong, S. and Patarametha, M. (1991) Subsurface Stratigraphy of the Non-Marine Mesozoic Khorat Group, Northeastern Thailand. Proceedings of GEOSEA 7th Conference, Bangkok, 5-8 November 1991.

[27] Buffetaut, E. and Suteethorn, V. (1992) A New Species of Ornithischian Dinosaur Psittacosaurus from the Early Cretaceous of Thailand. Palaeontology, 35, 801-812.

[28] Tabakh, M.E., Schreiber, B.C., Utha-Aroon, C., Coshell, L. and Warren, J.K. (1998) Diagenetic Origin of Basal Anhydrite in the Cretaceous Maha Sarakham Salt: Khorat Plateau, NE Thailand. Sedimentology, 45, 579-594. http://dx.doi.org/10.1046/j.1365-3091.1998.00162.x

[29] Suwanich, P. (2007) Potash-Evaporite Deposits in Thailand. GEOTHAI 07 International Conference on Geology of Thailand: Towards Sustainable Development and Sufficiency Economy, Bankok, 252-262.

[30] Booth, J. and Sattayarak, N. (2011) Subsurface Carboniferous-Cretaceous Geology of NE Thailand. In: Ridd, M.F., Barber, A.J. and Crow, M.J., Eds., The Geology of Thailand, Geological Society, London, 185-222.

[31] Suwanich, P. (1983) Potash and Rock Salt in Thailand. Conference on Geology and Mineral Resources of Thailand,. Department of Mineral Resources, Bangkok, 19-28 November 1983, 244-252.

[32] Department of Mineral Resources (2013) Geological Standard Division. Bureau of Geological Survey. Lexicon of Stratigraphic Names of Thailand, 271 p.

[33] Wiegand, B., Dietzel, M., Bielert, U., Groth, P. and Hansen, B.T. (2001) ${ }^{87} \mathrm{Sr} /{ }^{86} \mathrm{Sr}-$ Verhältnisse als Tracer für Hydrochemische Prozesse in Einem Lockergesteinsaquifer (Libenau, NW Deutschland). Acta Hydrochimica et Hydrobiologica, 29, 139-152. http://dx.doi.org/10.1002/1521-401X(200109)29:2/3<139::AID-AHEH139>3.0.CO;2-Z

[34] Klaus, J.S., Hansen, B.T. and Buapeng, S. (2007) ${ }^{87} \mathrm{Sr} /{ }^{86} \mathrm{Sr}$-Ratios: A Natural Tracer to Characterize the Groundwater of Bangkok Area, Thailand, with Respect to Public Water Supply and Freshwater Reinjection. Hydrogeology Journal, 15, 745-758. http://dx.doi.org/10.1007/s10040-007-0175-z

[35] Wemmer, K. and Ahrendt, H. (1997) Comparative K-Ar and Rb-Sr Age Determinations of Retrograde Processes on Rocks from the KTB Deep Drilling Project. Geologische Rundschau, 86, 272-285. http://dx.doi.org/10.1007/PL00014660

[36] Howarth, R.J. and McArthur, J.M. (1997) Statistics for Strontium Isotope Stratigraphy: A Robust LOWESS Fit to the 
Marine Strontium Isotope Curve for the Period 0 to 206 Ma, with Look-Up Table for the Derivation of Numerical Age. The Journal of Geology, 105, 441-456. http://dx.doi.org/10.1086/515938

[37] Mearon, S., Paytan, A. and Bralower, T.J. (2003) Cretaceous Strontium Isotope Stratigraphy Using Marine Barite. Geology, 31, 15-18. http://dx.doi.org/10.1130/0091-7613(2003)031<0015:CSISUM>2.0.CO;2

[38] Mattenklot, M. (1995) Modelberechnungen zur Br- und Rb-Verteilung in Carnallitgesteinen. Kali und Steinsalz Band 11, Heft 10.

[39] Suwanich, P. (2010) Potassium Bromide (KBr) Contents in the Maha Sarakham Formation. Journal of Science and Technology Mahasarakham University, 29, 249-258.

Submit or recommend next manuscript to SCIRP and we will provide best service for you:

Accepting pre-submission inquiries through Email, Facebook, LinkedIn, Twitter, etc.

A wide selection of journals (inclusive of 9 subjects, more than 200 journals)

Providing 24-hour high-quality service

User-friendly online submission system

Fair and swift peer-review system

Efficient typesetting and proofreading procedure

Display of the result of downloads and visits, as well as the number of cited articles

Maximum dissemination of your research work

Submit your manuscript at: http://papersubmission.scirp.org/ 